\title{
The Impact of Corporate Governance on the Financial, Governance and Social Disclosure at Islamic Banks in Malaysia
}

\author{
Asri Marsidia , Hairul Azlan Annuar ${ }^{\mathrm{b}}$, Abdul Rahim Abdul Rahman ${ }^{\mathrm{c}}$ \\ ${ }^{a}$ Faculty of Economics and Business, Universiti Malaysia Sarawak, Malaysia \\ ${ }^{b}$ Kulliyyah of Economics and Management Sciences, International Islamic University Malaysia, Malaysia \\ ${ }^{c}$ Universiti Sains Islam Malaysia, Malaysia
}

\begin{abstract}
The study examines the impact of board and audit committee on the disclosure of Islamic financial and social reporting (IFSR) among Islamic banks in Malaysia. Drawing on surveys this study seeks the views of accountants working in Islamic banks regarding the importance of items in the IFSR index developed by Marsidi et al. (2016). The annual reports are thereafter used to examine the score of the IFSR for the Islamic banks as well as to collect the data for the related variables. The multivariate regression findings suggest that board size is a significant factor in explaining the IFSR at Islamic banks in Malaysia. Such finding indicates that the size of board, which is represented by the number of directors who sit on the board of directors, is a crucial governance mechanism in achieving the aims of Islamic banks. The result also meets the role of corporate governance from the perspective of Islamic agency theory. The results of the study should not be generalised to year's prior, or after, the years of examination. The finding is perceived as contributing towards the suitable formation of board of directors specifically in terms of the total number of directors with respect to the financial, governance and social disclosures at Islamic banks. The study uses the Islamic agency theory to explain the governance practices and IFSR disclosures within the context of Malaysian Islamic banks. As such, the paper contributes towards the development and sustainability of Islamic banks both in Malaysia and throughout the globe.
\end{abstract}

Keywords: Board of Directors, Audit Committee, Islamic Agency Theory, IFSR Index, Disclosures, Islamic Banks

(C) IIUM Press

\section{Introduction}

The growing importance of Islamic banking industry reflects the need to understand issues associated to the relationship between the disclosure (i.e. financial and social) and corporate governance practices. In this respect, the board and audit committee are perceived as the governance mechanisms responsible to ensure appropriate discharge of corporate accountability through effective corporate financial disclosures (Vafeas, 2005).

Hence, it is necessary to examine the corporate governance practices on the financial and social disclosure at Islamic banks considering the important roles of the board and audit committee on corporate financial disclosure. The findings are expected to provide valuable insights on the effects of the board and audit committee on the financial and social reporting practices at Islamic banks. The results may also be used as a platform to understand the relationship and provide useful information for the formation of the board and audit committee in Islamic banks.

The issues concerning corporate financial reporting are also vital to be tackled due to the information asymmetry problems and the agency conflicts that exist between corporate managements and stakeholders (Healy \& Palepu, 2001). Corporate disclosures are hence considered as a bridge between corporations and users of corporate financial information. Corporate financial reporting denotes the disclosure of both financial and non-financial information (Gibbin et al., 1990).

The information can be in the form of quantitative or qualitative, mandatory or voluntary and released through formal or informal channels. The issues of quantitative, qualitative, mandatory, and voluntary 